\title{
Algılanan Örgütsel Desteğin İşgören Performansına Etkisinde İşe Adanmışlı̆̆ın Aracı Etkisi
}

\section{The Mediating Role of Work Engagement on the Impact of Perceived Organizational Support on Employee Performance}

\author{
Metin Işsı, ${ }^{a, *}$ Aycan Kama ${ }^{b}$ \\ ${ }^{a}$ Dr. Öğr. Üyesi, Bitlis Eren Üniversitesi, İktisadi ve İdari Bilimler Fakültesi, İşletme Bölümü, 13000, Bitlis/Türkiye \\ ORCID: 0000-0003-4577-0095 \\ b Kahramanmaraş Sütçü İmam Üniversitesi, Sosyal Bilimler Enstitüsü, İşletme Bölümü, 46040, Kahramanmaraş/Türkiye. \\ ORCID: 0000-0001-5008-9072
}

\section{MAKALE BILLGİİ}

Makale Geçmişi:

Başvuru tarihi: 14 Eylül 2017

Düzeltme tarihi: 20 Ocak 2018

Kabul tarihi: 01 Şubat 2018

\section{Anahtar Kelimeler:}

Algılanan Örgütsel Destek

İşgören Performansı

İşe Adanmışlik

Aracı Etki

\section{ARTICLE INFO}

\section{Article history:}

Received 14 September 2017

Received in revised form 20 January 2018

Accepted 01 February 2018

\section{Keywords:}

Perceived Organizational Support

Employee Performance

Work Engagement

Mediating Effect

\section{ÖZ}

$\mathrm{Bu}$ araştırmanın amacı, çalışanların örgütsel destek algılarının iş performanslarına etkisinde işe adanmışlığın aracı rolünü tespit etmektir. Bu amaçla, Tatvan/Bitlis ilinde farklı branşlarda görev yapan ve araştırmaya gönüllü katılım sağlayan $n=378$ öğretmen araştırmanın örneklemi olarak seçilmiştir. Veri toplamak amacıyla anket yöntemi kullanılmış olup, kolayda örneklem yoluna gidilmiştir. Uygulanan anketlerden elde edilen veriler sonucunda değișkenler arasındaki ilişkileri tespit etmek amacıyla korelasyon analizi yapılmıştır. Değişkenlere yönelik doğrulayıcı faktör analizi ile aracı etkinin tespit edilmesi için ise yapısal eşitlik modellemesi kullanılmıştır. Analiz sonuçlarına göre örgütsel desteğin, işe adanmışlık ve işgören performansı üzerinde etkili bir faktör olduğu görülmüş ve algılanan örgütsel desteğin, işgören performansı üzerindeki etkisinde fiziksel adanmışlığın kısmi aracı etkiye sahip olduğu tespit edilmiştir.

\section{A B S T R A C T}

The purpose of this research is to determine the mediating role of engagement to work in the impact of employees perceptions of organizational support on employee performance. For this purpose, $n=378$ teachers who worked in different branches in the province of Tatvan/Bitlis participated in the research voluntarily and they were selected as the sample of the research. Survey method was used for collecting data and convenience sampling method was used. As a result of the data obtained from the applied questionnaires, a correlation analysis was performed in order to determine the relations between the variables. Confirmatory factor analysis for variables and structural equation modeling were used to determine the mediator's effectiveness. According to the results of the analysis, organizational support was found to be an effective factor on work engagement and employee performance and it was found that perceived organizational support has a partial mediating effect on physical engagement while affecting employee performance.

\section{Giriş}

Örgütsel destek çalışma veya sosyal hayatta olmak üzere işgörenlerin ihtiyacını yakından hissettiği ve düzeyini her zaman sorguladığı bir kavram olmuştur. Neticede beşeri bir varlık olan insan hayatının pek çok evresinde desteğe ihtiyaç duymaktadır. Örgütsel destek kavramı Blau'nun Sosyal Mübadele Kuramına dayanmaktadır. Blau' ya göre örgütler ile işgörenler arasındaki ilişkiler bir çeşit değiş-tokuşa dayanır ve her biri bu süreçte kendi çıkarlarını maksimize etmeye çalışır. Eisenberger vd. (1986) karşılıklı takas esasına dayanan Sosyal Mübadele Kuramının, örgütsel süreçlerde; işgörenlerin örgüt hakkındaki olumlu algılarının, onlarda davranış ve tutum değişikliklerine yol açabileceğini belirterek örgütsel destekle ilgili çalışmalar yapmaya başlamışlardır. Yaptıkları çalışmalarda algılanan örgütsel desteği; işgörenler tarafindan örgütün onlara değer vermesi ve onların refahını düşünmesinin algılanması olarak tanımlamışlardır (Erdem, 2014: 82-83). İşgörenlerin yüksek performans sergilemelerinde, işlerine ve örgütlerine yönelik

\footnotetext{
* Sorumlu yazar/Corresponding author.

e-posta: imetin@beu.edu.tr
} 
adanma duygusunun gelişmesinde örgütsel destek önemli faktörlerden bir tanesidir. Bu desteğin işgörenler tarafından yeterince hissedilememesi durumunda ise, başta iş stresi olmak üzere, tükenmişlik, kuruma yönelik sinik tutumlar, ișten ayrılma eğilimi ve işgören devamsızlı̆̆ı (absenteeism) gibi pek çok olumsuz etkilerinin olabileceği birçok araştırmada belirtilmiştir.

İşe adanmışlık işgörenin işi ile bütünleşmesi ve işine yönelik geliştirmiş olduğu tutum ve davranışladır (Chusmir, 1982: 596). İşgörenlerin işlerine yönelik adanma duygusu fiziksel, zihinsel veya duygusal olarak farklı biçimlerde gerçekleşebilir. İşgörenlere adanma duygusu noktasında enerji kazandıran kaynaklar; pozitif bir örgüt kültürü, yetki devri, personel güçlendirme, etkin bir iletişim, düşük güç mesafesi veya örgüt kaynaklarının adil paylaşılması gibi etkenler olabileceği birçok araştırmada belirtilmiştir. İşe adanmışlık çalışmaya ilişkin güçlü bir bağlılığı temsil etmekte ve önemlilik hissiyatı, ilham, gurur ve mücadele olgularını kapsar. İşe adanmışlık duygusu gelişmiş olan bireylerin işlerinin önemli olduğunu, mücadele gerektirdiğini, belirli bir amaca hizmet ettiğini ve anlamlı olduğunu düşünürler; yaptıkları iş onlara ilham verir, dolayısıyla işlerini hevesle yaparlar ve işleriyle gurur duyarlar (Çalışkan, 2014: 370-371).

Performans, işgörenlerin amaçları, görevleri veya hedefleri gerçekleştirebilme düzeylerini veya buna ilişkin çabalarını ifade eden bir kavramdır. Örgütün türü ne olursa olsun mutlaka uygun standartlarla işgörenlerin performans ölçümleri yapılmalıdır. Çünkü ölçemediğimiz bir şeyi sağlıklı bir şekilde yönetemeyiz. Örgüt tarafindan işgörenlere sağlanan destek, arzulanan performans hedeflerine ulaşmayı kolaylaştırmaktadır. İşgörenler kendilerini örgütün bir parçası olarak hissettiklerinde ve örgüt ile aralarında duygusal bir bağ kurulduğunda performansları yükselmektedir ve bu durum algılanan örgütsel destek ile gerçekleşmektedir. İşgörenlerin algıladıkları örgütsel desteğin artışı ile işgörenlerin örgüte karşı duygusal bağlılıklarının, örgüte daha fazla katılımının ve örgüt amaçlarına ulaşma çabalarının da artacağ Eisenberger vd. (1986) ve bunun sonucunda da işe yönelik adanma duygularının gelişebileceği söylenebilir.

Yapılan literatür taramasında algılanan örgütsel destek, işe adanmışlık ve işgören performansı değişkenlerini birlikte değerlendiren çalışmaların olmadığı görülmüştür. Ayrıca söz konusu değişkenlerin genellikle özel sektör veya hastane çalışanları üzerinde yapıldığı gözlemlenmiştir. Dolayısıyla, araştırmamızda algılanan örgütsel destek, işgören performansı ve işe adanmışlık değişkenlerini birlikte incelemek ve saha araştırmasının da genel olarak adanma duygusunun yüksek olduğu öğretmenler üzerinde yapılmasının literatürel ve ampirik bir katkı sunması beklenmektedir.

\section{Teorik Çerçeve}

\subsection{Alg1lanan Örgütsel Destek}

Örgütün işgörenlerine değer vermesi, işgörenlerin olumlu veya olumsuz her türlü durumunda onları yalnız hissettirmemek için örgüt desteğini işgörenlere göstermesi ve de işgörenlerinin beklentilerinin karşılanmasına önem verilmesi algılanan örgütsel desteğin tanımını oluşturmaktadır ve bu kavram işgörenlerin örgüte karşı duygusal bir bağ kurmasında oldukça etkili olmaktadır (Turunç ve Çelik, 2010: 184). Kısacası algılanan örgütsel destek, örgüt tarafından işgörenlerin örgüte olan katkılarının ve refahlarının ne derece değerli görüldüğünü içermektedir ve algılanan örgütsel destek sayesinde işgörenlerin iş devamsızlıklarında azalmanın olacağı ve de işgörenlerin beklentilerine yönelik örgüt amaçları doğrultusunda gösterilen çabaların ödüllendirilebileceğini varsayılmaktadır (Eisenberger vd., 1986: 500). İşgörenlerin örgüt tarafından değer görmesi ve önemsenmesi konusunda ki algılamalar ayrıca örgütün işgörenlerinin tutum ve davranışlarını tanımalarını ve onları ödüllendirme sorumluluklarını yerine getireceklerine olan güveni artırmalıdır. Bu ödüller ise övgü, rehberlik gibi gayri resmi olabileceği gibi promosyon, maaş artışı gibi resmi de olabilir (Wayne vd., 1997: 83).

Algılanan örgütsel destek, işgörenlerin örgütün kendilerine destek vermelerini bekledikleri birçok durum olduğunu ifade etmektedir. Bunlar örgütten, gelecekte meydana gelebilecek hastalıklarına, hatalarına ve yüksek performanslarına karşı muhtemel tepkisini ve örgütün işgörenlerine karşı adil maaş ödemelerine yönelik isteklerdir (Eisenberger vd., 1986: 501). Ayrıca algılanan örgütsel destek ile işgörenlerin üstün performans sergilediklerine yönelik çıkarımlarını artırmalı ve çalışanların başarıları örgütü gururlandırmalıdır, bunun sayesinde saygınlık ihtiyacı karşılanmış olacaktır (Armeli vd., 1998: 289). Örgütsel bağl1lıkta yükselme ve işgörenlerin işten ayrılmalarında azalma olması da yine algılanan örgütsel desteğin artışı ile mümkün olacaktır (Ekmekçioğlu ve Sökmen, 2016: 35).

Örgütsel desteğin, işgörenlerin fikir, öneri ve eleştirilerine her zaman önem verme, çalışanlarına iş güvenliği sağlama ve başarıları karşısında iş garantisi verme, örgüt içi iletişimin güçlü olmasını sağlama, herkese eşit davranma, işgörenlerini önemseme özelliklerine sahip olması gerekmektedir. Bu özellikler işgörenlerine önem veren, onların huzur ve refahlarını önemseyen ve onlara destek olan bir örgütte olması gereken özelliklerdir (Özdevecioğlu, 2003: 117). Algılanan örgütsel destekte, işgörenlerin övgü ve onay ihtiyaçları karşılandığında, kendilerini örgüt ile özdeşleştirirler ve örgütle aralarında duygusal bir bağ geliştirilmiş olur. $\mathrm{Bu}$ sayede duygusal bağlılık, çalışan performansı, örgüte daha fazla katılım ve örgütün amaçlarına ulaşma çabaları artacaktır (Eisenberger vd., 1986: 501). Çalışanların örgüt içerisinde kabul gördüğünü hissetmesi, örgütün bir parçası olması ve örgüt ile duygusal bir bağ kurması anlamına gelen örgütsel özdeşleşmenin, işgörenlerde örgütte kalma isteği gibi birçok olumlu sonuçları olmaktadır (Turunç ve Çelik, 2010: 184).

\section{2. İşe Adanmışlık}

Adanmışlık kavramı; katılım, taahhüt, tutku, heyecan ve odaklanmış çabayı ifade etmektedir (Schaufeli ve Bakker, 2010: 11). İşe adanmışlık ise, işgörenlerin işlerinde severek çaba göstermelerini, işlerine odaklanmalarını ifade etmektedir. $\mathrm{Bu}$ nedenle işe adanmışlık, iş görenlerin gösterdikleri performansları üzerinde önemli bir etkiye sahiptir (Turhan vd., 2012: 180). Bir işgörenin işe adanmışlığı, çalışma arkadaşları ile arasındaki iletişime, hizmet sunduğu kişiler ile iletişimine, yapmakta olduğu işin kalitesine ve de meslektaşlarının işleri hakkında 
sergiledikleri tutum ve davranışlara bağlı olmaktadır (Sağsan ve Firtına, 2015: 7).

İşgörenler kendilerini işlerine ne kadar çok adarlarsa örgüt amaçlarını benimsemeleri de o kadar artacaktır. İşe adanmışlığı olan işgörenler, örgütün amaçlarını benimserler ve bu amaçların gerçekleştirilmesi için büyük çaba sarf ederler. İşgörenler örgütleri için fedakârlık yapmaktan çekinmeyecek ve böylece örgütle özdeşleşmiş olacaklar, işlerini gönüllü olarak yapacakları düşünülmektedir. İşgörenlerin adanmışlıklarını sağlamada en önemli faktör ise, onların örgüte karşı güven duygularını sağlamaktır (Celep, 1998: 56; Demirhan ve Karaman, 2015: 246). Güven duygusunun sağlanmasıyla örgüt ile bireyin amaçlarında gittikçe bütünleşme olacaktır ve bu sayede işe adanmışlığın, hem örgüt hem de birey açısından verimliliği arttıran bir kavram olacağ1 düşünülmektedir (Taştan, 2014: 93).

İşe adanmışlığın etkilenmiş olduğu mesleğe bağlılık, bireysel, psiko-sosyal, örgütsel ve diş faktörler gibi faktörlerin yönetiminin etkin ve doğru şekilde yapılması ile bireylerin tükenmişlik düzeylerinin azalacağı ve bu sayede örgüt açısından olumsuzluklarında azalacağı düşünülmektedir (Keleş, 2014: 98). İşine adanmış çalışanlar enerjik olmakla kalmazlar, ayrıca bu enerjilerini işlerine de uygularlar ve yaptıkları çalışmaların enerjilerini hak ettiğini düşündükleri gibi, yaptıkları işi eğlenceli bulurlar ve bu eğlenceyi de etkin bir eyleme dönüştürürler (Leiter ve Bakker, 2010: 2). İşe adanmışlığı olan işgörenler, işlerini zevkle yaptıkları için beklenti ve mutlulukları da kısmen karşılanmış olmaktadır. $\mathrm{Bu}$ nedenle işe adanmışlıkları yüksek olan işgörenlerin, yaptıkları iş, aldıkları ücret ve yönetim tarzı gibi konular hakkında olumlu tutumları olacaktır (Özyılmaz ve Süner, 2015: 147).

\section{3. İşgören Performans1}

Performansın tanımı, belirlenmiş zamanda üretilmekte olan mal veya hizmet miktarı olarak yapılmaktadır, birey için performansın tanımı yapılacak olursa amaçlara ulaşmak için bireylerin göstermiş olduğu verimlilik ve etkinliğin derecesidir (Tutar ve Altınöz, 2010: 201). Performansın sözlükte yer alan tanımının ise "bir işin üstesinden gelmek, muvaffakiyet veya bir kimsenin kendisine düşen görevi etkili bir biçimde tamamlaması" olduğu görülmektedir.

İşi gerçekleştiren birey veya grubun amaca yönelik yaptıkları işin nereye ulaşabildiğinin miktar ve kalite bakımından ifade edilmesidir (Esin, 2013: 40). İşgörenlerin göstermiş oldukları iş performansları ve verimlilikleri işletmelerin başarısında rol oynayan en önemli faktörlerden birisidir (Kale, 2014: 104). İstek, beklenti ve ihtiyaçları karşılanan iş görenler moral ve motivasyon bakımından işlerinde daha etkin ve verimli olacaklardır. Moral ve motivasyonu yüksek iş görenlerin örgüte bağlılıkları artacak ve bu doğrultuda iş performansları da artacaktır (Uygur, 2007: 71). Aksi takdirde istek, ihtiyaç beklentileri karşılanmayan işgörenlerden beklenen verimin elde edilmesi oldukça zordur. Örgütün amaçlarına ulaşabilmesi iş görenlerin motivasyonlarının sağlanması ve kendilerini örgüt içerisinde mutlu ve sağlıklı hissetmeleri ile mümkündür (Yazıcıoğlu, 2010: 243). Bunlara ek olarak örgüt içerisinde kendilerini güvende hissetmeyen iş görenlerin, işlerine odaklanmakta zorlandıkları, devamlı bir gerginlik ve huzursuzluk hissettikleri görülmektedir. Günden güne artmakta olan işsizlik ve işten çıkarılmalar da iş görenlerin işletmeye karşı güvensizlik hissetmelerine neden olarak iş performanslarını olumsuz yönde etkilemektedir (Gerşil ve Aracı, 2011: 46).

Örgüt içerisinde algılanan örgütsel destek ve iş görenlerin yaşadıkları stres, iş görenlerin örgüte ve işe olan yaklaşımlarını etkilemektedir. İşverenlerin işgörenlerden beklentisi performanslarında artış olurken, iş görenler ise çalışma şartlarının kendilerine uygun bir şekilde düzenlenmesini ve örgütün kendilerine destek olmasını beklemektedirler. İş görenlerin örgüt ile psikolojik bağ kurması yani örgütsel özdeşleşmenin sağlanmasının da iş gören performansını olumlu yönde etkileyeceği düşünülmektedir (Turunç ve Çelik, 2010: 183).

Örgütsel bağlılığın sağlanması, işgörenlerin istek ve beklentilerinin karşılanması, performanslarında artış sağlayacaktır ve böylece örgüt için oldukça önemli bir konu olan müşteri memnuniyeti de sağlanabilecektir. Çünkü istek ve beklentileri karşılanan iş görenlerin işlerinde daha etkin ve verimli olmaları söz konusudur (Uygur, 2007: 72).

Bir örgütün iyi olması işgörenlerin performanslarına bağlıdır. Bu nedenle de iş görenlerin göstermiş oldukları performans örgüt başarısında önemli bir yere sahiptir. İşgörenlerin performanslarında ki artış örgüt performansını da olumlu etkileyecektir ve bu olumlu sonuçların oluşabilmesi içinse, işgörenlerin işlerini anlamlı bulmaları, kendilerinin yetkin ve özerk olduklarını düşündükleri bir iş ortamının sağlanması gerekmektedir (Çöl, 2008: 45).

Hipotezlerin kuramsal çerçevesi;

Algılanan örgütsel desteğin, işgörenlerin görev sorumluluklarını yerine getirmeleri için gerekli fiziksel, bilişsel ve duygusal çabaları ortaya koymalarında bir rolü söz konusudur. Söz konusu destek işgörenler tarafindan yeterli düzeyde algılandığında işgörenler örgüt üyesi olmaktan ve kendilerini işlerine adamaktan memnuniyet duymaktadırlar (Biswas ve Bhatnagar, 2013; İnce, 2016). Diğer taraftan algılanan örgütsel destek ile işgören performansı arasındaki ilişkiyi araştıran pek çok çalışmada algılanan örgütsel desteğin işgörenlerin performansını pozitif yönde etkilediği görülmektedir (Grandey, 1997; Cropanzano, 1999; Allen, vd., 2003; Kraimer, 2004; Akkoç vd., 2012). Son olarak işe adanmışlı̆̆ın işgören performansı ilişkisine bakıldığında işgörenlerin mesleklerine ya da çalıştıkları kuruma yönelik adanmışlıkları performanslarını artırdığı pek çok çalışmada bulgulanmıştır (Salanova vd., 2005; Bakker ve Bal 2010; Rich vd., 2010).

Yukarıda değişkenler arası kuramsal bağlamlardan yola çıkarak çalışmanın hipotezleri aşağıdaki gibi oluşturulmuştur:

$\mathrm{H}_{1}$ : Algilanan örgütsel desteğin performansa etkisinde işe adanmışlığın duygusal boyutunun aracı rolü vardır.

$\mathrm{H}_{2}$ : Algılanan örgütsel desteğin performansa etkisinde işe adanmışlığın fiziksel boyutunun aracı rolü vardır.

$\mathrm{H}_{3}$ : Algilanan örgütsel desteğin performansa etkisinde işe adanmışlığın bilişsel boyutunun aracı rolü vardır.

$\mathrm{H}_{4}$ : Algılanan örgütsel desteğin performans üzerinde anlamlı bir etkisi vardır.

Algılanan örgütsel desteğin performansa etkisinde işe adanmışlığın bir aracılık etkisinden söz edebilmek için 
oluşturulacak yapısal eșitliklerde Baron ve Kenny'nin (1986) önerdiği üç koşulun sağlanması gereklidir. Birinci koşul, birinci eşitlikte bağımsız değişkenin aracı değişkeni etkilemesi, ikinci koşul, ikinci eşitlikteki bağımsız değișkenlerin bağımlı değișken üzerinde bir etkisinin olması, üçüncü koşulda ise, üçüncü eşitlikteki aracı değişkenin bağımlı değişkeni etkilemesidir. Eğer bu tüm koşullar sağlanırsa üçüncü eşitlikteki bağımsız değişkenin bağımlı değişken üzerindeki etkisinin ikinci eșitliktekinden daha az olması durumunda bir aracılık etkisinden söz etmek olasıdır (Ciraklar vd., 2016: 77). Bu bağlamda araştırmanın modeli aşağıdaki gibi geliştirilmiştir.

Şekil 1. Araştırmanın Modeli

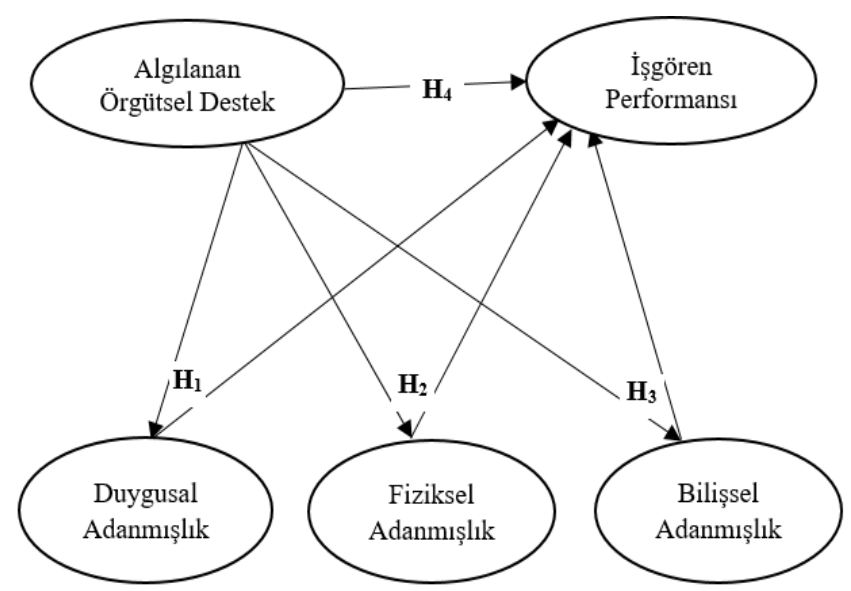

\section{Araştırmanın Yöntemi}

Katılımcılara ait demografik bilgiler aşağıda Tablo 1' de belirtilmiștir.

Tablo 1. Katılımcıların Demografik Bilgileri

\begin{tabular}{|c|c|c|c|}
\hline \multicolumn{2}{|l|}{ Değişkenler } & $\mathrm{f}$ & $\%$ \\
\hline \multirow{3}{*}{ Cinsiyet } & Kadın & 146 & 38,6 \\
\hline & Erkek & 232 & 61,4 \\
\hline & Toplam & 378 & 100,0 \\
\hline \multirow{6}{*}{ Yaş } & $21-26$ & 115 & 30,4 \\
\hline & $27-32$ & 165 & 43,7 \\
\hline & $33-38$ & 74 & 19,6 \\
\hline & $39-44$ & 18 & 4,8 \\
\hline & 45 ve üzeri & 6 & 1,6 \\
\hline & Toplam & 378 & 100,0 \\
\hline \multirow{3}{*}{$\begin{array}{l}\text { Medeni } \\
\text { Durum }\end{array}$} & Evli & 195 & 51,6 \\
\hline & Bekar & 183 & 48,4 \\
\hline & Toplam & 378 & 100,0 \\
\hline \multirow{6}{*}{$\begin{array}{l}\text { Meslek } \\
\text { Tecrübesi }\end{array}$} & 1 y1ldan az & 40 & 10,6 \\
\hline & $1-4$ & 159 & 42,1 \\
\hline & $5-9$ & 107 & 28,3 \\
\hline & $10-14$ & 51 & 13,5 \\
\hline & 15 y1l üzeri & 21 & 5,6 \\
\hline & Toplam & 378 & 100,0 \\
\hline \multirow{5}{*}{ Okul Türü } & Anaokulu & 4 & 1,1 \\
\hline & İlkokul & 95 & 25,1 \\
\hline & Ortaokul & 160 & 42,3 \\
\hline & Lise & 119 & 31,5 \\
\hline & Toplam & 378 & 100,0 \\
\hline
\end{tabular}

Araştırmanın temel amacı örgütsel desteğin performansa etkisinde işe adanmışlığın aracı etkisinin olup olmadığını tespit etmektir. Araştırmanın ana kütlesini Tatvan/Bitlis'te farklı branş ve okullarda görev yapan öğretmenler oluşturmaktadır. Örneklem olarak araștırmaya gönüllü katılım sağlayan 378 öğretmen seçilmiştir. Veri toplamak amaciyla anket yöntemi benimsenmiş olup kolayda örneklem yoluna gidilmiştir. Buna göre, evreni oluşturan her elemanın örneğe girme şansı eşittir. Dolayısıyla hesaplamalarda da her elemana verilecek ağırlık aynıdır (Arıkan, 2004: 141). Hazırlanan anket formu araştırmanın örneklemini oluşturan öğretmenlere mesai saatleri içerisinde dağıtılmıştır. Öğretmenlerin ders yoğunluğu dikkate alınarak kendilerinden anket formunu mesai saatleri dişında daha rahat bir şekilde yanıtlamaları istenmiştir. Böylelikle veri toplama sürecinde öğretmenlerin herhangi bir şekilde zaman veya başka bir baskı altında kalmadan sağlıklı bir değerlendirme yapacakları düşünülmüştür.

\subsection{Araştırmanın Ölçekleri}

Örgütsel Destek Ölçeği (OD): Katılımcıların algıladıkları örgütsel desteği ölçmek için Turunç vd. (2010) tarafından Türkçe geçerlemesi yapılan ve Erdem (2014)'ün araştırmasında yer alan ölçek kullanılmıştır. Ölçekte 10 ifade yer almakta olup, ölçeğe ilişkin yapılan doğrulayıcı faktör analizi sonucunda ölçeğin tek boyuttan oluştuğu görülmüştür. Algılanan örgütsel destek değişkeni için yapılan doğrulayıcı faktör analizi sonucunda model uyum iyiliği değerleri sağlanamadığından önerilen düzeltmeler yapilarak modelde yer alan 6 . ve 7. ifadeler sirayla modelden çıkarılarak model revize edilmiş ve kabul edilebilir uyum iyiliği değerleri sağlanmıştır. Ölçekte yer alan 6 . ve 7 . ifadelerin faktör yükleri düşük çıktığından bu ifadeler analize tabi tutulmamıştır. Kalan ifadelere ait faktör yüklerinin $(, 513)$ ile $(, 863)$ arasında değerler aldığı görülmüştür. Örgütsel destek değişkeni için yapılan güvenilirlik analizinde Cronbach's Alpha $(\alpha)=, 860$ olarak bulunmuştur.

İşe Adanmışlık Ölçeği (IA): Katılımcıların işe adanmışlık düzeylerini ölçek için Rich vd. (2010) tarafından hazırlanan 18 ifade ve üç boyuttan (Duygusal, Fiziksel ve Bilişsel) ölçeğin Türkçe geçerlemesi yapılarak kullanılmıștır. Ölçeğe yönelik yapılan doğrulayıcı faktör analizinde ölçeğin üç boyuttan oluştuğu görülmüştür. Faktör yüklerinin $(400)$ ile $(, 861)$ arasında değerler aldığı görülmüştür. İşe adanmışlık değişkeni için yapılan güvenilirlik analizinde Duygusal boyut $\alpha=, 905$, Fiziksel boyut $\alpha=, 863$, Bilişsel boyut $\alpha=, 825$ İşe Adanmışlık tümü için $\alpha=, 935$ olarak bulunmuştur.

Performans Ölçeği (P): Katılımcıların performans çabalarını ölçmek için Sigler ve Pearson (2010) tarafından hazırlanan ve Çöl (2008) tarafindan Türkçe geçerlemesi yapılan, 4 ifade ve tek boyuttan oluşan ölçek kullanılmıştır. Ölçekte yer alan ifadelere ait faktör yüklerinin $(, 610)$ ile $(, 834)$ arasında değerler aldığı görülmüştür. Performans değişkeni için yapılan güvenilirlik analizinde $\alpha=, 773$ olarak bulunmuştur.

Ankette yer alan bütün ifadeler 5'li Likert tipinde hazırlanmış ve katılımcılara hangi katılım düzeyinde onayladıkları sorulmaktadır. Değişkenlere yönelik yapılan güvenilirlik analizi değerlerinden de görüleceği üzere ölçeklerin güvenilir olduğu görülmüştür. Ölçeklerin faktör yapılarını ölçmek için AMOS paket programı ile doğrulayıcı faktör analizi yapılmıştır. 


\subsection{Verilerin Analizi ve Bulgular}

Aşağıda Tablo 2'de değişkenlere ait tanımlayıcı istatistikler verilmiştir. Ölçeklerin ortalamalarına bakıldığında işe adanmışlık değişkeni 3,99 ile en yüksek ortalamaya sahip iken örgütsel destek değişkeninin 3,42 ile en düşük ortalamaya sahip olduğu görülmüştür. Öğretmenlerin işe adanmışlık değişkenine ait ortalamanın yüksek çıkması onların mesleklerine olan adanmışlık düzeylerinin yüksek olduğunu göstermektedir. Diğer taraftan örgütsel desteğin en düşük ortalama olarak çıkması da öğretmenlerin başta okul idaresi olmak üzere ilgili diğer yöneticiler tarafindan istedikleri veya bekledikleri ölçüde desteklenmedikleri şeklinde değerlendirilebilir.
Tablo 2'de korelasyon değerlerine bakıldığında işe adanmışlık değişkenin boyutları arasında yüksek düzeyde pozitif ilişkiler olduğu görülmektedir. Algılanan örgütsel destek ve işe adanmışlık değişkenleri arasında pozitif ve orta düzey ilişki, yine bu iki değişken ile işe adanmışlık boyutları arasında da orta düzey pozitif ilişkiler olduğu görülmüştür.

Araştırmada kullanılan ölçeklere ilişkin yapılan AMOS programı yardımı ile yapılan doğrulayıcı faktör analizi sonuçları yukarıda Tablo 3' te belirtilmiştir. Uyum iyiliği değerlerinin belirlenmesinde literatürde yaygın kullanılan "kabul edilebilir uyum iyiliği değerleri" esas alınmıştır. Ölçeklerin uyum iyiliği değerlerinin oldukça iyi olduğu gözlenebilir.

Tablo 2. Değişkenlere İlişkin Tanımlayıcı İstatistikler ve Korelasyon Katsayıları

\begin{tabular}{|c|c|c|c|c|c|c|c|}
\hline Değişkenler & Ort. & 1 & 2 & 3 & 4 & 5 & 6 \\
\hline 1. Duygusal Adanmışlık & 4,0410 & - & $0,621 * *$ & $0,548 * *$ & $0,851 * *$ & $0,490 * *$ & $0,471 * *$ \\
\hline 2. Fiziksel Adanmışlik & 4,0898 & & - & $0,730 * *$ & $0,896 * *$ & $0,349 * *$ & $0,488 * *$ \\
\hline 3. Bilişsel Adanmışlık & 3,8577 & & & - & $0,859 * *$ & $0,380 * *$ & $0,462 * *$ \\
\hline 4. İşe Adanmışlik & 3,9961 & & & & - & $0,473 * *$ & $0,546^{* *}$ \\
\hline 5. Örgütsel Destek & 3,4275 & & & & & - & $0,413 * *$ \\
\hline 6. Performans & 3,8689 & & & & & & - \\
\hline
\end{tabular}

**Korelasyon $\mathrm{p}<0.01$ düzeyinde anlamlıdır (2-yönlü).

Tablo 3. Ölçeklerin Doğrulayıcı Faktör Analizi Uyum İyiliği Değerleri

\begin{tabular}{lccccccc}
\hline & CMIN/DF < & GFI >.850 & AGFI >.800 & CFI >.900 & NFI >.900 & TLI >.900 & RMSEA < .080 \\
\hline Örgütsel Destek & 2,837 &, 966 &, 936 &, 971 &, 956 &, 957 &, 070 \\
Performans & 1,766 &, 998 &, 977 &, 998 &, 995 &, 988 &, 045 \\
İşe Adanmışlik & 2,964 &, 896 &, 862 &, 934 &, 904 &, 922 &, 072 \\
\hline
\end{tabular}

Şekil 2. Ana Model

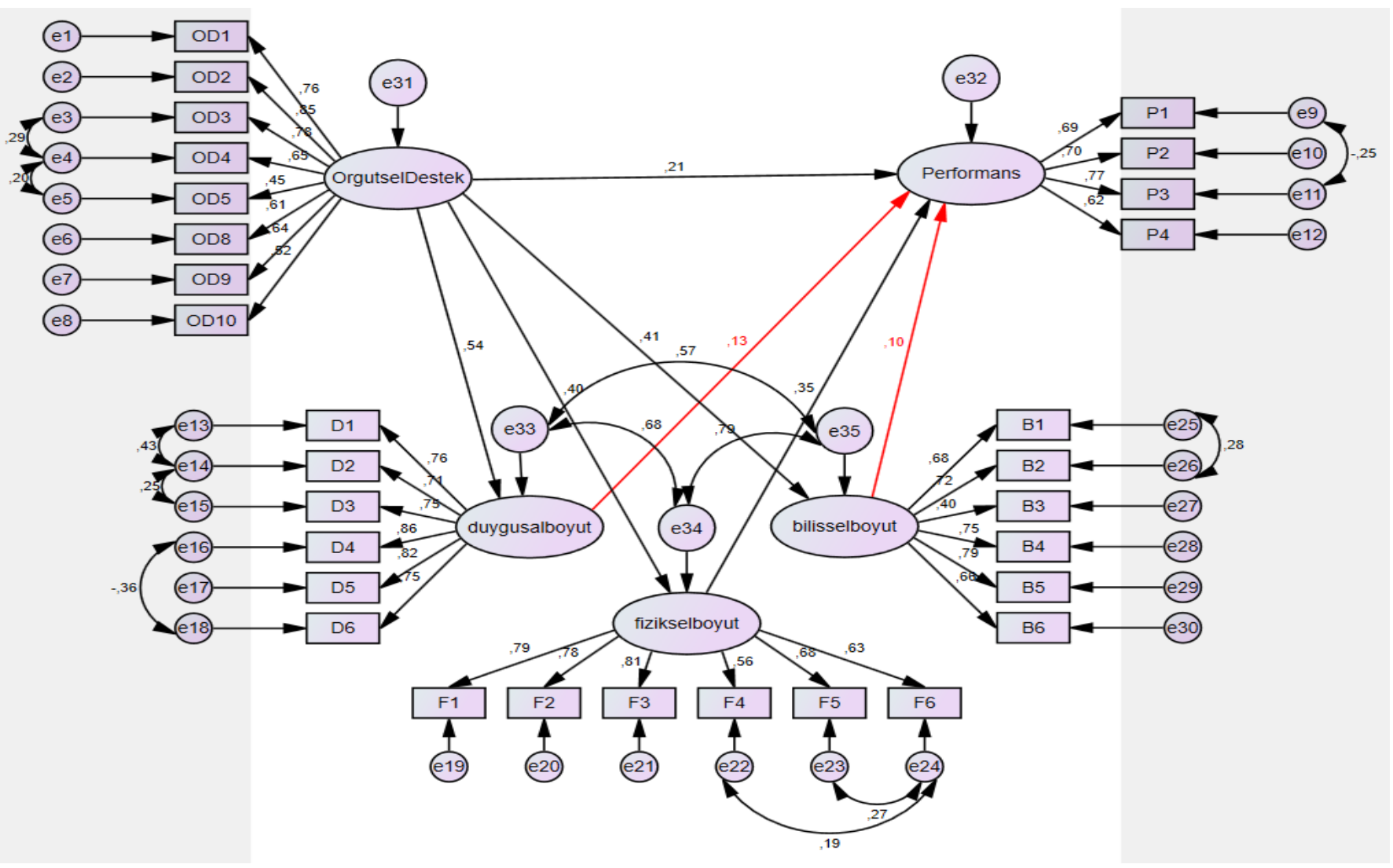


Araştırma amacına yönelik olarak Şekil 2'de çizilmiş olan YEM modelini test etmek için path analizi yapılmıştır. Modele ait uyum iyiliği değerleri; $\mathrm{CMIN} / \mathrm{DF}=2,320, \mathrm{GFI}=$ .862, AGFI $=.834, \quad$ CFI $=.914, \quad \mathrm{NFI}=.903, \quad \mathrm{TLI}=.904$ ve RMSEA $=.059$ şeklinde tespit edilmiştir. Analiz sonuçlarına göre modelin iyi uyum gösterdiği görülmektedir.

Tablo 4. Ana Model-1'e Ait Regresyon ve Anlaml1lık Değerleri

\begin{tabular}{lllll}
\hline Regresyon & & & Estimate & $\mathrm{P}$ \\
\hline duygusalboyut & $<---$ & OrgutselDestek &, 661 & $* * *$ \\
fizikselboyut & $<---$ & OrgutselDestek &, 415 & $* * *$ \\
bilisselboyut & $<---$ & OrgutselDestek &, 451 & $* * *$ \\
Performans & $<---$ & OrgutselDestek &, 220 &, 001 \\
Performans & $<---$ & duygusalboyut &, 108 &, 158 \\
Performans & $<---$ & bilisselboyut &, 100 &, 359 \\
Performans & $<---$ & fizikselboyut &, 354 &, 009 \\
duygusalboyut & $<---$ & OrgutselDestek &, 661 & $* * *$ \\
fizikselboyut & $<---$ & OrgutselDestek &, 415 & $* * *$ \\
bilisselboyut & $<---$ & OrgutselDestek &, 451 & $* * *$ \\
\hline
\end{tabular}

Analiz sonuçlarına ilişkin regresyon ve anlamlılık değerleri yukarıda Tablo 4' te belirtilmiştir. Path analizi sonucunda uyum iyiliği değerlerine ilişkin bazı parametrelerin istenilen aralıkta olmadığı görülmüş ve programın önermiş olduğu modifikasyonlar sırası ile yapılmıştır. Önerilen modifikasyonların genel olarak ișe adanmışlık değișkenin üç boyutuna ait hata terimleri arasında olduğu görülmektedir. $\mathrm{Bu}$ durum temel olarak değişkenin alt boyutları arasındaki yüksek ilişkiyi de açıklamaktadır. Uyum iyiliği değerini kabul edilebilir sınırlar içerisine çekebilecek değișiklikleri yapmak için Ana Model analiz çıktıları kısmında gerekli modifikasyonlar incelenmiş ve işe adanmışlık değişkeninin hata terimleri arasında programın önermiş olduğu kovaryanslar sırasıyla oluşturulup analizler yapılmıştır.

Son analiz ile birlikte modele ilişkin uyum iyiliği değerlerinin kabul edilebilir sınırlar içerisinde olduğu Ana Model'e ait uyum iyiliği değerlerinden anlaşılmaktadır. Bununla birlikte oluşturulan kovaryansların modeli anlamlı bir şekilde geliştirip geliştirmediği ki-kare fark istatistiğinden (Bayram, 2013: 117) bakılmış ve bağlantıların modeli anlamlı bir şekilde geliştirdiği görülmüştür. Ancak model üzerindeki yollar incelendiğinde işe adanmışlık değişkeninin (aracı değişken) duygusal ve bilişsel boyutlarının performans üzerinde anlamlı bir etkisinin olmadığı (Tablo'4 ve Şekil 2 de kırmızı ile işaretli) görülmüş ve bu iki değişken modelden çıkarılmış ve yeniden analiz yapılmıştır. Bu durumda $\mathrm{H}_{1}$ ve $\mathrm{H}_{3}$ hipotezleri reddedilmiştir. Analiz edilen model aşağıdaki şekilde belirtilmiştir.

Şekil 3. Revize Ana Model

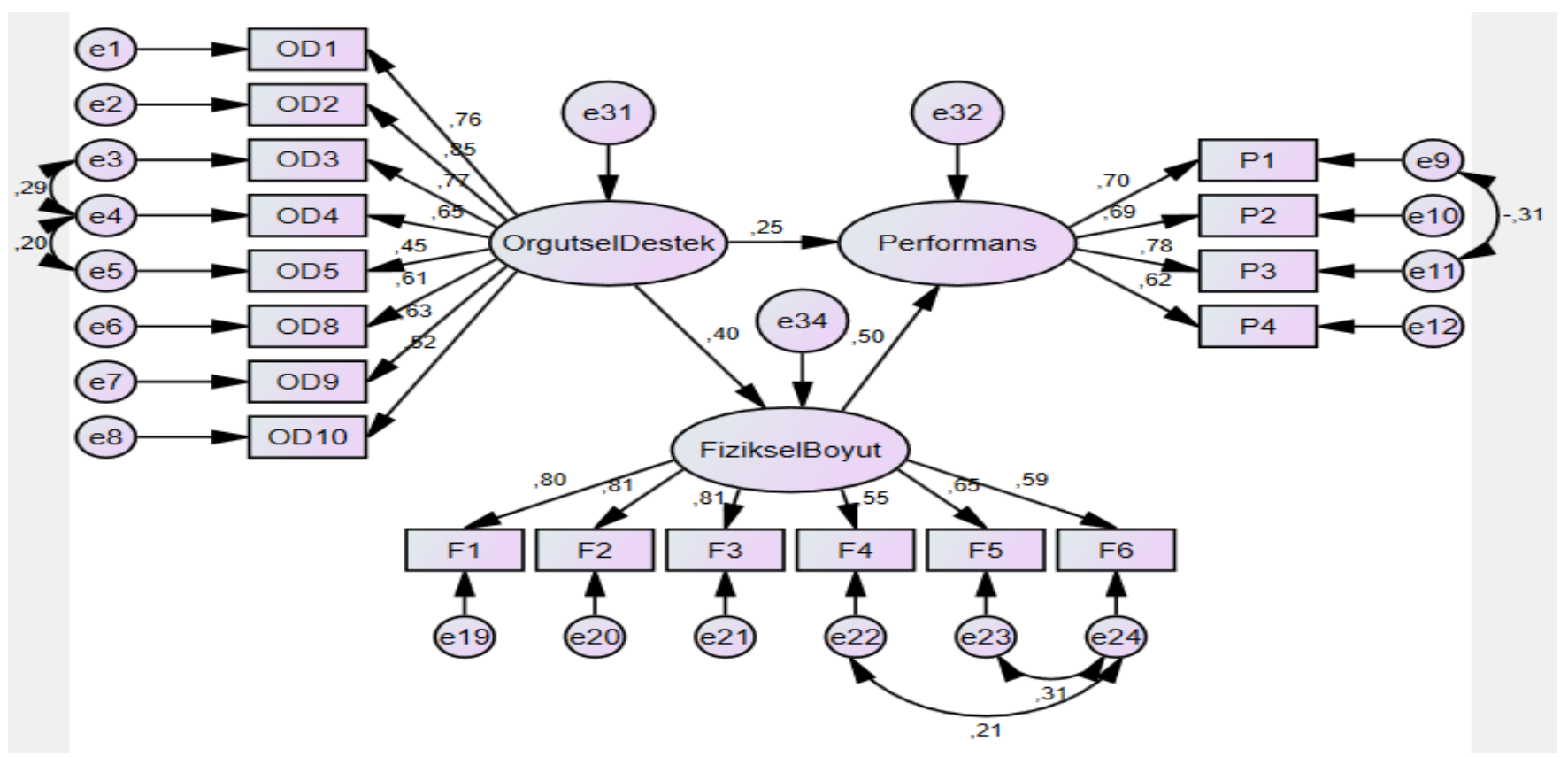

Revize edilen YEM modelini test etmek için path analizi yapılmıştır. Modele ait uyum iyiliği değerleri; $\mathrm{CMIN} / \mathrm{DF}=2,490, \quad \mathrm{GFI}=.915, \quad \mathrm{AGFI}=.885, \quad \mathrm{CFI}=.935$, $\mathrm{NFI}=.921, \mathrm{TLI}=.896$ ve $\mathrm{RMSEA}=.063$ şeklinde tespit edilmiştir. Analiz sonuçlarına göre model uyum iyiliği değerlerinin kabul edilebilir sınırlar içerisinde olduğu ve değişken birbirilerini anlamlı şekilde (Tablo 4) etkilediği görülmüştür.

Tablo 4. Revize Ana Modele Ait Regresyon ve Anlamlılik Değerleri

\begin{tabular}{lcccc}
\hline Regresyon & & & Estimate & $\mathrm{P}$ \\
\hline FizikselBoyut & $<---$ & OrgutselDestek &, 392 & $* * *$ \\
Performans & $<---$ & OrgutselDestek &, 273 & $* * *$ \\
Performans & $<---$ & FizikselBoyut &, 552 & $* * *$ \\
\hline
\end{tabular}

Analiz sonucunda herhangi bir modifikasyon önerilmeden modelin uyum iyiliği değerlerinin oldukça iyi olduğu görülmüştür. Ancak örgütsel destek ve performans değişkenleri arasındaki ilişkinin anlamsız çıkmaması işe adanmışlık değişkenine ait fiziksel boyutunun örgütsel destek ve performans arasında tam aracılık rolünün olmadığını göstermiştir. Fakat kısmi aracılık rolünün olup olmadığını anlamak için örgütsel destek ve performans arasındaki ilişkiye ait regresyon katsayısına (Şekil 3) bakılması gerekmektedir. Bu durum, Baron ve Kenny'nin (1986) ikinci koşulunu test etmek açısından önem taşımaktadır. Bu amaçla Şekil 4' te belirtildiği gibi örgütsel desteğin performans üzerindeki etkisini ölçmeye yönelik model analiz edilmiştir. 
Şekil 4. Örgütsel Desteğin Performans Üzerindeki Etkisi

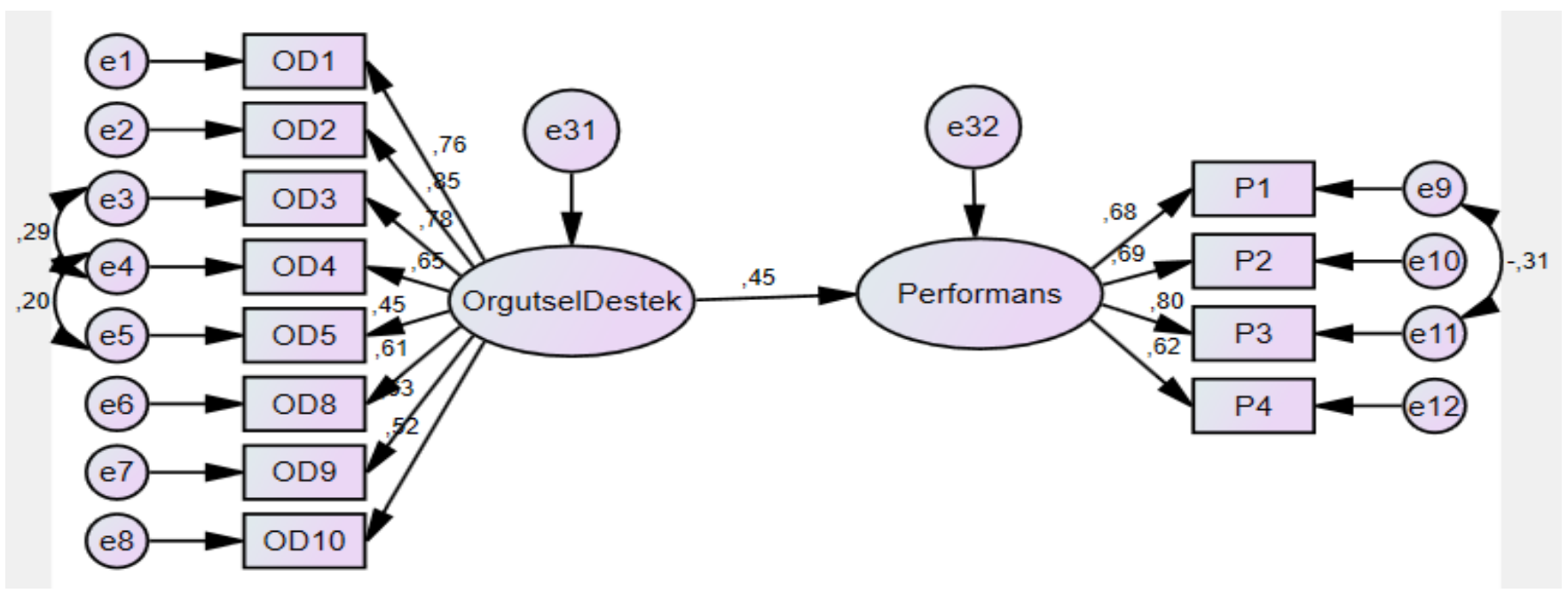

Örgütsel desteğin performans üzerindeki etkisini test ekmek üzere yapılan modele ait uyum iyiliği değerleri; $\mathrm{CMIN} / \mathrm{DF}=2,654, \quad \mathrm{GFI}=.947, \quad \mathrm{AGFI}=.917, \quad \mathrm{CFI}=.951$, $\mathrm{NFI}=.936$, TLI $=.925$ ve $\mathrm{RMSEA}=.066$ şeklinde tespit edilmiştir. Analiz sonuçlarına göre modelin iyi uyum gösterdiği görülmektedir.

Tablo 5. Örgütsel Desteğin Performans Üzerindeki Etkisi

\begin{tabular}{lllll}
\hline Regresyon & & & Estimate & $\mathrm{P}$ \\
\hline Performans & $<---$ & OrgutselDestek &, 474 & $* * *$ \\
Performans & $<---$ & FizikselBoyut &, 552 & $* * *$ \\
\hline
\end{tabular}

Tablo 5' te görüldüğü üzere algılanan örgütsel desteğin performans üzerinde anlamlı bir etkiye sahip olduğu tespit edilmiştir. Böylelikle araştırma hipotezlerinden $\mathrm{H}_{4}$ kabul edilmiştir.

Uyum iyiliği değerlerinin çok iyi olduğu modelden de anlaşılacağ1 üzere Revize Ana Model üzerindeki örgütsel destek değişkeninin performans üzerindeki regresyon katsayısının $(, 25)$ Model-3 e göre azaldığı izlenmektedir. Nitekim örgütsel destek değişkeninin performans değişkeni üzerindeki etkisine ilişkin Model 3 te izlenen regresyon katsayısının $(, 45)$ olduğu görülmektedir. Bu durum, Baron \& Kenny (1986) in aracı etki için belirtmiş olduğu; bağımlı değişkenin bağımsız değişken üzerindeki etkisinin azalması veya tamamen ortadan kalkması gerekir koşulunu sağlamaktadır. Belirtilen bu durumdan hareketle, işe adanmışlık değişkenine ait fiziksel boyutun algılanan örgütsel desteğin performans üzerindeki etkisinde kısmi aracılık etkisinin olduğu sonucuna varılmış ve $\mathrm{H}_{2}$ hipotezi kabul edilmiştir.

\section{Sonuç ve Değerlendirme}

$\mathrm{Bu}$ çalışmanın amacı algılanan örgütsel destek, işe adanmışlık ve işgören performansı arasındaki ilişkileri incelemek ve algılanan örgütsel desteğin işgören performansına etkisinde işe adanmışlığın aracılık etkisini ortaya koymaktır. Araştırma sonucunda elde edilen bulgular algılanan örgütsel desteğin; işgören performansı ve işe adanmışlık değişkenleri ile anlamlı şekilde orta düzeyde ilişkiye sahip olduğunu göstermektedir. Algılanan örgütsel desteğin performansa etkisinde işe adanmışlığın aracı etkisini ortaya koymak amacıyla yapısal eşitlik modellemesi ile yapılan analiz sonucunda fiziksel adanmışlık boyutunun aracılık rolünün olduğu tespit edilmiştir. Araştırmada bir diğer sonuç olarak, ölçeklerin ortalamalarına bakıldığında öğretmenlerin işe adanmışlık duygularının yüksek olduğu görülmüştür. Benzer şekilde işe adanmışlık değişkenini öğretmenler üzerinde inceleyen Celep (1998) ve Celep vd.,'nin (2004) de araştırmasında öğretmenlerin işe adanma duygularının yüksek olduğu tespit edilmiştir. Bu durumun nedeni olarak, toplumumuzda öğretmenlik mesleğinin yüce, kutsal ve çok değerli bir meslek olarak görülmesi ve bu gibi nedenlerden dolayı öğretmenlere kendilerinin kıymetli hissettirilmesinin etkisi olduğu düşünülmektedir. Çünkü araştırmada öğretmenlerin algıladıkları örgütsel desteğin en düşük ortalamaya sahip olmasına rağmen işe adanmışlık ve performans ortalamalarının yüksek çıkması bahsedilen veya benzeri nedenlerden kaynaklandığını göstermektedir.

Araştırma sonucunda algılanan örgütsel destek ile işgören performansı arasında pozitif yönlü anlamlı bir ilişki tespit edilmiştir. Bu bulgu, Eisenberger et al., (1986), Lynch vd., (1999), Rhoades ve Eisenberger (2002), Cropanzano (1999), Rich vd., (2010) ve Akkoç vd., (2012)' nin araştırma bulguları ile uyumlu olduğu tespit edilmiştir. Örgüt tarafından desteklenen çalışanların daha yüksek performans gösterdikleri söylenebilir. Benzer şekilde algılanan örgütsel destek ile işe adanmışlık arasında pozitif yönlü anlamlı bir ilişki tespit edilmiştir. Bu sonuç, Zacher vd., (2011), Caesens ve Stinglhamber (2014) ve İnce (2016)' nin araştırmalarındaki bulgu ile benzerlik göstermektedir. Elde edilen bulgular algılanan örgütsel desteğin, ise adanmışlık üzerinde etkili bir faktör olduğunu göstermiştir. Bu sonuca göre çalışanların örgütsel destek algıları yükseldikçe, işe adanmışlık düzeyleri de yükselmektedir denilebilir. İşe adanmışlık ve işgören performansı ilişkisine bakıldığında ise, işe adanmışlık değişkeninin bütün boyutları ile performans arasında pozitif yönlü ilişkiler olduğu görülmüştür. $\mathrm{Bu}$ sonuç Rich vd., (2010)' nun araştırmalarındaki bulgu ile desteklenmektedir. Bu durumda, işe adanmışlık duygusu yüksek olan işgörenlerin daha yüksek performans gösterebilecekleri şeklinde değerlendirilebilir.

Çalışmanın sadece Bitlis'in Tatvan ilçesindeki öğretmenler üzerine yapılmış olması, çalışma bulgularının genelleştirilebilmesini güçleştiren bir kısıt olmaktadır. Konuya yönelik ileride köy, kasaba, il merkezi veya özel eğitim kurumlarında görev yapan öğretmenler üzerine 
yapılacak çalışmaların bu konuya ilişkin bulguların genelleştirilebilmesini mümkün kılacaktır. Çalışama, kullanılan değişkenlerin birbirileri ile olan ilişkisi ve aracı etkinin yapısal eşitlik modelli kullanılarak öğretmenler üzerinde yapılması bakımından bir ilktir. İleride yapılacak araştırmalarda algılanan örgütsel desteğin işgören performans üzerindeki etkisinde işe adanmışlığın aracılık etkisi farklı ölçekler, farklı örneklem grupları ve farklı analiz yöntemleri (örneğin hiyerarşik regresyon) ile incelenmesinin ve işe adanmışlığın tam aracı etkisinin olup olmadığının araştırılması bu konuya yönelik kuramsal katkı sağlayabileceğini söyleyebiliriz.

\section{Kaynakça}

Akkoç, İ., Çalişkan, A., \& Turunç, Ö. (2012). Örgütlerde gelişim kültürü ve algılanan örgütsel desteğin iş tatmini ve iş performansına etkisi: güvenin aracılık rolü. Yönetim ve Ekonomi: Celal Bayar Üniversitesi İktisadi ve İdari Bilimler Fakültesi Dergisi, 19(1), 105-135.

Allen, D., Shore, L.M., \& Griffeth, R.W. (2003). The role of perceived organizational support and supportive human resource practices in the turnover process. Journal of Management, 29, 99-118.

Arıkan, R. (2004). Araştırma Teknikleri ve Rapor Hazırlama. Asil Yayın: Ankara.

Armeli, S., Eisenberger, R., Fasolo, P., \& Lynch, P. (1998). Perceieved organizational support and police performance: the moderating influence of socioemotional needs. Journal of Applied Psychology, 83(2), 288-297.

Bakker, A. B., \& Bal, M. P. (2010). Weekly work engagement and performance: A study among starting teachers. Journal of Occupational and Organizational Psychology, 83(1), 189-206.

Baron, R. M., \& Kenny, D. A. (1986). The moderatormediator variable distinction in social psychological research: conceptual, strategic, and statistical considerations. Journal of Personality and Social Psychology, 51(6), 1173-1182.

Bayram, N. (2013). Yapısal Eşitlik Modellemesine Giriş Amos Uygulamalarl. Bursa: Ezgi Kitabevi.

Biswas, S., \& Bhatnagar, J. (2013). Mediator analysis of employee engagement: role of perceived organizational support, PO fit, organizational commitment and job satisfaction. Vikalpa, 38(1), 27-40.

Caesens, G., \& Stinglhamber, F. (2014). The relationship between perceived organizational support and work engagement: The role of self-efficacy and its outcomes. European Review of Applied Psychology, 64(5), 259-267.

Celep, C. (1998). Eğitim örgütlerinde öğretmenlerin örgütsel adanmışlığı. Eğitim ve Bilim, 22(108), 56-62.

Celep, C., Doyuran, Ş., Sarıdede, A. G. U., \& Değirmenci, A. G. T. (2004). Eğitim örgütlerinde çok boyutlu iş etiği ve örgütsel adanmışlık. XIII. Ulusal Eğitim Bilimleri Kurultayı, 6-9 Temmuz, İnönü Üniversitesi, Eğitim Fakültesi, Malatya
Chusmir, L. H. (1982). Job commitment and the organizational woman. Academy of Management Review, 7(4), 595-602.

Ciraklar, N. H., Ucar, Z., \& Sezgin, O. B. (2016). Effects of paternalistic leadership on organizational identification: mediating role of trust in leader. Research Journal of Business and Management, 3(1), 73-87.

Cropanzano, R. (1999). Organizational politics and organizational support as predictors of work attitudes, job performance, and organizational citizenship behavior. Journal of Organizational Behavior, 20(2), 159-174.

Çalışkan, S. C. (2014). Pozitif örgütsel davranış değişkenleri ile yeni araştırma modelleri geliştirme arayışları: Pozitif örgütsel davranış değişkenlerinin işe adanmışlık, tükenmişlik ve sinizm üzerine etkileri ve bu etkileşimde örgütsel adalet algısının aracılık rolü üzerine bir araştırma. Dokuz Eylül Üniversitesi Sosyal Bilimler Enstitüsü Dergisi, 16(3), 363-382.

Çöl, G. (2008). Algılanan güçlendirmenin işgören performansı üzerine etkileri. Doğuş Üniversitesi Dergisi, 9(1), 35-46.

De Oliveira Maciel, C., \& Camargo, C. (2016). Social connection in organizations: the effects of local ties on job engagement and performance. Revista de Administração, 51(4), 377-385.

Demirhan, M. F., \& Karaman, A. (2015). Akademisyenlerin adalet ve etik algılarının örgütsel adanmışlıklarına etkisi. Uşak Üniversitesi Sosyal Bilimler Dergisi, 8(4), 245-266.

Eisenberger, R., Huntington, R., Hutchison, S., \& Sowa, V. (1986). Perceived organizational support. Journal of Applied Psychology, 71(3), 500-507.

Ekmekçioğlu, E. B., \& Sökmen, A. (2016). Algılanan örgütsel desteğin işten ayrılma niyetine etkisinde örgütsel bağlılığın aracı rolü: sınır birimi çalışanları üzerine bir araştırma. International Review of Economics and Management, 4(2), 32-45.

Erdem, H. (2014). Algllanan Örgütsel Destek ve Kontrol Odağının Stresle Başa Çıkma Yöntemleri Üzerine Etkileri: Psikolojik Sermayenin Bu Süreçteki Rolü ve Bir Alan Araştırması. Doktora Tezi. Malatya: İnönü Üniversitesi.

Esin, F. (2013). Hizmet içi eğitim kalitesinin iş gören performansina etkisi: bir uygulama. Yüksek Lisans Tezi. İstanbul: Beykent Üniversitesi.

Gerşil, G. S., \& Aracı, M. (2011). Sosyal sermayenin güven unsurunun işgörenlerin performansı üzerine etkileri. Çalışma ve Toplum, 1, 39-74.

Grandey, J. (1997). The relationship of organizational politics and support to work behaviors, attitudes, and stres. Journal of Organizational Behavior, 18(2), 159180.

İnce, A. R. (2016). Algılanan örgütsel desteğin işe adanmışlık üzerindeki etkisinde yönetici desteğinin aracılık rolü. Elektronik Sosyal Bilimler Dergisi, 15(57), 649-660. 
İnce, A. R., (2016). Algılanan örgütsel desteğin işe adanmışlık üzerindeki etkisinde yönetici desteğinin aracılık rolü. Elektronik Sosyal Bilimler Dergisi, 15(57), 649-660.

Kale, E. (2014). Lider desteği ve iş arkadaşları desteğinin iş performansı üzerine etkileri: iş tatmini ve yaşam tatmininin aracı rolü. Uluslararası Íktisadi ve Ídari Incelemeler Dergisi, 14,103-120.

Keleş, S. (2014). Aile şirketlerinde y jenerasyonunun öz yeterlilik algısı ve işe adanmışlık ilişkisi. Süleyman Demirel Üniversitesi Vizyoner Dergisi, 5(11), 95-109.

Kraimer, M. (2004). An examination of perceived organizational support as a multidimensional construct in the context of an expatriate assignment. Journal of Management, 30(2), 209-237.

Leiter, M. P., \& Bakker, A. B. (2010). Work engagement: introduction, work engagement a handbook of essential theory and research, 1-9.

Lynch, P. D., Eisenberger, R., \& Armeli, S. (1999). Perceived organizational support: inferior versus superior performance by wary employees. Journal of Applied Psychology, 84(4), 467.

Özdevecioğlu, M. (2003). Algılanan örgütsel destek ile örgütsel bağlılık arasındaki ilişkilerin belirlenmesine yönelik bir araştırma. Dokuz Eylül Üniversitesi İktisadi ve idari Bilimler Fakültesi Dergisi, 18(2), 113-130.

Özyılmaz, A., \& Süner, Z. (2015). İşe adanmışlığın işyeri tutumlarına etkisi: Hatay'daki 9 işletmede yapılan ampirik araştırmanın sonuçları. Eskişehir Osmangazi Üniversitesi IIIBF Dergisi, 10(3), 143- 164.

Rhoades, L., \& Eisenberger, R. (2002). Perceived organizational support: a review of the literature. Journal of Applied Psychology, 87(4), 698-714.

Rich, B. L., Lepine, J. A., \& Crawford, E. R. (2010). Job engagement: Antecedents and effects on job performance. Academy of Management Journal, 53(3), 617-635.

Rich, B. L., Lepine, J. A., \& Crawford, E. R. (2010). Job engagement: antecedents and effects on job performance. Academy of Management Journal, 53(3), 617-635.

Sağsan, M., \& Fırtına, B. (2015). Bilgi mesleğine bağlılık ve adanmışlık: platonik bir ilişkinin gelgitleri ve profesyonellikle imtihanı. Bilgi Dünyası, 16 (1), 1-22.

Salanova, M., Agut, S., \& Peiró, J. M. (2005). Linking organizational resources and work engagement to employee performance and customer loyalty: the mediation of service climate. Journal of Applied Psychology, 90(6), 1217.

Schaufeli, W. B., \& Bakker, A. B. (2010). Defining and measuring work engagement: Bringing clarity to the concept. In: A. B. Bakker \& M. P. Leiter (Eds.), Work engagement: A handbook of essential theory and research, (pp. 10-24). New York, NY: Psychology Press.
Taştan, S. (2014). Örgüt iklimi ile örgütsel adanmışlık arasındaki ilişkide psikolojik güçlendirme algısının ara değişken olarak incelenmesi ve psikososyal kaynakların rolü: kamu kesim çalışanları üzerine bir araştırma. Organizasyon ve Yönetim Bilimleri Dergisi, 6(1), 91106.

Turhan, M., Demirli, C., \& Nazik, G. (2012). Sınıf öğretmenlerinin mesleğe adanmışlık düzeyine etki eden faktörler: Elazı̆ örneği. İstanbul Ticaret Üniversitesi Sosyal Bilimler Dergisi, 11(21), 179-192.

Turunç, Ö., \& Çelik, M. (2010). Çalışanların algıladıkları örgütsel destek ve iş stresinin örgütsel özdeşleşme ve iş performansına etkisi. Yönetim ve Ekonomi, 17(2), 183206.

Tutar, H., \& Altınöz, M. (2010). Örgütsel iklimin işgören performansı üzerine etkisi: ostim imalât işletmeleri çalışanları üzerine bir araştırma. Ankara Üniversitesi SBF Dergisi, 65(2), 195-218.

Uygur, A. (2007). Örgütsel bağlılık ile işgören performansı ilişkisini incelemeye yönelik bir alan araştırması. Ticaret ve Turizm Eğitim Fakültesi Dergisi, 1, 71-85.

Wayne, S. J., Shore, L. M., \& Liden, R. C. (1997). Perceieved organizational support and leader-member exchange: a social exchange perspective. Academy of Management Journal, 40(1), 82-111.

Yazıcıoğlu, İ. (2010). Örgütlerde iş tatmini ve işgören performansı ilişkisi: Türkiye ve Kazakistan karşılaştırması. Bilig, (55), 243-264.

Zacher, H., \& Winter, G. (2011). Eldercare demands, strain, and work engagement: The moderating role of perceived organizational support. Journal of Vocational Behavior, 79(3), 667-680. 